\title{
Reconstructing black identity: The Black Panther, Frantz Fanon and Achilles Mbembe in conversation
}

\begin{tabular}{|c|c|}
\hline \multicolumn{2}{|c|}{$\begin{array}{l}\text { Author: } \\
\text { Jaco Beyers }{ }^{1} \text { (D) }\end{array}$} \\
\hline \multicolumn{2}{|c|}{$\begin{array}{l}\text { Affiliation: } \\
{ }^{1} \text { Department of Biblical and } \\
\text { Religious Studies, Faculty } \\
\text { of Theology, University } \\
\text { of Pretoria, Pretoria, } \\
\text { South Africa }\end{array}$} \\
\hline \multicolumn{2}{|c|}{$\begin{array}{l}\text { Research Project Registration: } \\
\text { Project Leader: J. Beyers } \\
\text { Project Number: } 02440237\end{array}$} \\
\hline \multicolumn{2}{|c|}{$\begin{array}{l}\text { Description: } \\
\text { This research is part of th } \\
\text { research project, 'Religior } \\
\text { Theology and Education', } \\
\text { directed by Prof. Dr Jaco } \\
\text { Beyers, Programme Mana } \\
\text { Biblical and Religious Stuc } \\
\text { and member of the } \\
\text { Department of Science of } \\
\text { Religion and Missiology, } \\
\text { Faculty of Theology and } \\
\text { Religion, University of } \\
\text { Pretoria. }\end{array}$} \\
\hline \multicolumn{2}{|c|}{$\begin{array}{l}\text { Corresponding author: } \\
\text { Jaco Beyers, } \\
\text { jaco.beyers@up.ac.za }\end{array}$} \\
\hline \multicolumn{2}{|c|}{$\begin{array}{l}\text { Received: } 20 \text { Mar. } 2019 \\
\text { Accepted: } 15 \text { July } 2019 \\
\text { Published: } 30 \text { Oct. } 2019\end{array}$} \\
\hline \multicolumn{2}{|c|}{$\begin{array}{l}\text { How to cite this article: } \\
\text { Beyers, J., 2019, } \\
\text { 'Reconstructing black } \\
\text { identity: The Black Panther, } \\
\text { Frantz Fanon and Achilles } \\
\text { Mbembe in conversation', } \\
\text { HTS Teologiese Studies/ } \\
\text { Theological Studies 75(4), } \\
\text { a5469. https://doi.org/ } \\
\text { 10.4102/hts.v75i4.5469 }\end{array}$} \\
\hline \multicolumn{2}{|c|}{$\begin{array}{l}\text { Copyright: } \\
\text { (C) 2019. The Authors. } \\
\text { Licensee: AOSIS. This wo } \\
\text { is licensed under the } \\
\text { Creative Commons } \\
\text { Attribution License. }\end{array}$} \\
\hline \multirow{2}{*}{ 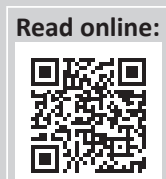 } & \\
\hline & $\begin{array}{l}\text { Scan this QR } \\
\text { code with your } \\
\text { smart phone or } \\
\text { mobile device } \\
\text { to read online. }\end{array}$ \\
\hline
\end{tabular}

It is dehumanising to identify people in terms of colour. Stereotyping and discrimination come with racial identification. Black identity has been expressed in different forms over the centuries. For a long period black identity was a constructed identity assigned to black people through a white-dominated matrix. After the end of slavery, efforts were made to reconstruct black identity. This developed into two divergent lines: one resulting in an illusionary identity as identified by Frantz Fanon and a second line of thought of a continued search for a true authentic black identity as explicated by the Cameroon-born philosopher Achilles Mbembe. This process of creating a new authentic black identity is still ongoing and viewed by some as a pessimistic futile attempt. An example of the ongoing attempt for establishing an authentic black identity is illustrated by the movie Black Panther, which attempts to portray a different side of being black.

Keywords: black identity; culture; race; religion; Mbembe; Fanon; Black Panther; postcolonialism.

\section{Introduction}

The movie Black Panther, released on 29 January 2018, is unique in many ways: the first black superhero to emerge from Hollywood, a movie blatantly and subtly criticising colonialism and a movie in an attempt to reconstruct black identity. Its uniqueness is marked by the many roles exclusively for actors of mixed race.

The intended audience is not only people of mixed race; in fact, it is a movie to be truly inclusive, a movie for 'everyone' (Zacharek 2018:88). The numerous awards awarded to the producers of the movie attest to the quality of the production and execution of the movie.

The fictional Black Panther becomes an international hero by fighting against crime and protecting his tribe living secretively hidden somewhere in Africa. The biggest challenge, however, for the Black Panther is to combat a rival tribal leader who has a legitimate claim to the throne. This contender derives from the West where his father was sent to act as an observer of what happens outside of the tribal borders. In the end, the inevitable tragedy occurs that one leader needs to die in order for the tribe to remain the powerful world leaders in advanced technology.

The movie portrays a black identity of an African community excelling in technological advancement and portraying an exemplary society - almost utopian like - as opposed to the rest of the world. Women are portrayed as having equal status to men, but still class differences exist between rulers coming from aristocracy and that of the commoners. However, being fictional, this movie presents real social issues relating to current inter-cultural and postcolonial societal dilemmas encountered worldwide.

The movie Black Panther presents a particular identity of blackness. This is however not recognisable as an existing reality in our world. The black identity known to the world is that of a created identity as presented through the lens of Western minds. New growing attempts at creating a black identity are only emerging now with all the challenges and limitations it may present. This article attempts to explore the processes of creating a black identity. It consists of a broad historic overview of existing and emerging identities. It culminates in a humble attempt at making suggestions as to how a black and white identity may be constructed.

This article is a contribution in dedication to the work of Prof. Maake Masango. Over his lifetime, Masango contributed to making an understanding of blackness. Through his efforts a responsible and Christian infused way of creating black identity has been created. The thoughts presented here are dedicated to his lifetime work. 


\section{Apparent thought on identity}

It is obvious that at the beginning of this article the question must be asked whether a non-black person can contribute to make the conversation on black identity. This article is not an attempt to prescription as to what black thought on this matter ought to be as we would have expected during colonial times where non-black persons would present prescriptive thoughts from a position of white dominance and misplaced attitude of superior knowledge. This consideration is an attempt to understand the relationship between religion and culture and determine the formative influence on creating identity, whatever it may be.

Identity consists of a conglomerate of markers, constitutive elements enabling one to differentiate one from others. Culture becomes the all-encompassing identity marker and differentiating factor. In the Foreword and Article 1 of the Universal Declaration on Cultural Diversity, culture and cultural diversity are defined as follows (UNESCO 2002):

Culture should be regarded as the set of distinctive spiritual, material, intellectual and emotional features of society or a social group, and it encompasses, in addition to art and literature, lifestyles, ways of living together, value systems, traditions and beliefs... Culture takes diverse forms across time and space. This diversity is embodied in the uniqueness and plurality of the identities of the groups and societies making up humankind. (p. 1)

Culture thus cannot be colour coded. Different races have internally different cultures. Then to talk about a black identity is somewhat misleading. A more appropriate signifier would be to discuss black identities by reflecting on the understanding that a race may consist of many different cultural entities. Maluleke (2000:26) warns that there is no united, homogeneous Africa or African identity: 'there are and should be many and various ways of being an African'. Fiction reflects reality in this regard. In the movie Black Panther, the community living in a fictional environment known as Wakanda is still divided along tribal lines. Each tribe has its own characteristics, features and unique culture. Although racially homogeneous the community is culturally diverse. A federal interdependence seems to exist among the tribes in Wakanda.

As the beliefs and spiritual elements present in a culture contribute to identity, it becomes obvious that religion can also be viewed as an identity marker. The matter is however more complex than what it seems. In many instances, culture and religion are inseparable. Elsewhere I have argued (Beyers 2017) that religion and culture can be considered as 'close relatives'. Religion is a cultural expression (Boyer 2001:47). Belonging to a particular culture does no longer imply that one belongs to a particular religion. Globalisation has resulted in multi-religious cultures all over the world. The main religions in Africa are African religion, Islam and Christianity. Coming from Africa does not automatically imply affiliation to African religion.
One, however, needs to heed the warning presented by Linda Woodhead $(2011: 112,119)$ that religion can function as a belief system or as an identity marker. As a belief system, religion is concerned with dogmas, doctrines and practices. As an identity marker, religion becomes a source of identity, either social or personal.

It is my contention that cultural identity, even if it is religiously determined, is ideologically motivated.

When identifying oneself according to a specific religion, it implies a juxtaposition of religion as a marker of identity, superseding all other markers. In this way, identity does not only say who you are, but also says who you are not. The own is emphasised over against the other. Statements about and claims on behalf of culture are motivated by the manifestation of a particular group (cf. Vroom 1996:118). A cultural-religious identity provides a feeling of certainty, meaning and belonging. When cultures meet, it can result in a 'hegemonic struggle' (Lincoln 1989:6-7) for power. Underlying such intercultural clashes (violent or non-violent) lies an in-depth search for and a need to affirm identity.

Cultural identity is not fixed but dynamic and in flux (Vroom 1996:118). This implies that cultures can have varying identities over time. These identities can be either assigned by others or self-constructed. This phenomenon becomes evident when considering the different black identities.

Regarding the process of creating identity, Appiah (2002:374) provides some insights into the process. Once a racial label (i.e. white, Asian or black) has been applied, certain social and psychological effects take place.

Manganyi (1973:35) indicates how the search for identity may result in identifying the personality of a group. The identity applied will contribute to the way in which people perceive themselves and their activities. The assigned label determines the identity (Appiah 2002:374). A label therefore causes social and psychological effects and shapes the self-conception, which eventually leads to the shaping of the self-identity. People then come to think of themselves in terms of the label assigned and conform their thoughts and actions according to the expectations based on the assigned label.

The implication of Appiah's theory is that identification shapes actions. Based on a label, certain behaviour associated with a race is expected and enacted (Appiah 2002:375). The result is that people treat others in a specific way and expect certain behaviour from them based on the assigned racial identity.

Those with the assigned label then respond by complying with the expectations. This results in an identity, an assumed identity assigned by others. We are however in need of authentic identities. There should be congruency between who I consider myself to be and how I express my identity. To consider my identity to be $X$ but live in 
a manner of $\mathrm{Y}$ because that is how others expect me to be is incongruent and inauthentic.

Authentic identity requires one to be true to oneself and not to conform to the image others expect from one. An authentic identity does not only include expressing the own preferences according to the own personality in a psychological perspective, but it also includes the freedom to express cultural preferences among people from different cultures (Appiah 2002:383). People should be true to their own culture. According Appiah (2002:383), a search for an identity is not a solo task to be performed in isolation. Dialogue shapes identity.

The individual in the process of establishing an authentic identity is provided with conversation partners in terms of religion, society, education, state and family. These become the informers and co-constructers for establishing an identity.

Appiah (2002:384) however warns against conversing with incorrect conversation partners. To consult white people on the matter of black identity would be counterproductive. Identity formation is the result of a process of engaging with the likeminded people and those with whom one can associate. In conversation with white people, Appiah (2002:384) argues that the black identity can only be rejected or acknowledged, but not as if the process is in need of white approval, but only to be taken note of. White people can no longer prescribe identity to others.

We may not have control over the concepts and influences provided by our society and culture to assist us in creating an identity, but we need the freedom to make the choices ourselves (Appiah 2002:383). Without this freedom we end up accepting a pre-determined identity created by others for us. This is what Mbembe (2017:12) calls an 'assigned identity'. This is an inauthentic identity. Humanity has a tainted history of assigned labels creating inauthentic identities.

\section{Colonial black identity}

One such inauthentic assigned identity can be found in the colonial period. For a long period, black identity was constructed according to a colonial matrix. The historical fact of colonialism needs to be recognised in order to come to an understanding of being-black-in-the-world (Manganyi 1973:37). Only relatively recently attempts, especially during the Black Consciousness Movement of the 1950s and the 1960s, were made to correct the colonial identity by reconstructing a black identity. Constructing the black identity is best done by those coming from Africa because it is 'on the African continent, where the great and intricate drama of being-black-in-the-world is taking place' (Manganyi 1973:3).

This process however followed divergent lines: one line resulting in a pseudonym as identity and a second line endeavouring to create a new authentic identity. The pseudonym resulted in a veiled identity of pretending to be a new identity, but in truth it was nothing else than a continuation of the old identity now only under the pretext of being new. Frantz Fanon is the most important figure to point to this fallacy, summarising the illusion of identity in the title of his (1986) book Black Skins, White Masks. Achilles Mbembe contributed to discussing the second line of thought, namely, the continued search for a new prevalent and emerging identity, an identity still under construction.

The whole matter of identifying as being black is problematic. The word 'black' conveys sentiment, stereotyping and meaning (Mbembe 2017:152). According to Mbembe, 'Black' is a name chosen by others to be given to someone. Nobody choose to be called as such. This name 'Black' is intended to bring one to a specific destination also not chosen. The name 'Black' is intended to be an insult and not intended to flatter (Mbembe 2017:152), a name functioning as objectification and degradation. Mbembe (2017:152) continues to indicate that 'black' as a colour implies that something is invisible darkness consumes it. In this way, that carrying the signifier as being black is meant to be invisible, obscure. This is based on the assumption made by Mbembe (2017:152) that the symbolic meaning of black is that of evil, murder and death. The sentiments surrounding black were expanded over centuries to come and denote something of inferior value.

How does one escape this assigned identity not chosen for?

During the colonial period, arguments were constructed in order to argue that races differ and some races are inferior to others. This argument was based on biological assumptions. The first of these theories, known as the recapitulation theory (cf. Gould n.d.), was based on the biological theories of Ernst Haeckel (1834-1919), who applied biological theories to sociological examples. Arguments based on Haeckel's theories wanted to indicate how from minor differences in the development of races one can argue that some races develop faster than other races and that therefore some races are biologically superior to other races.

The result was attempts at proving through evolutionary evidence white superiority and by implication inferiority of all other races. This contributed to create an identity of inferiority to be assigned to other races. 'Scientific proof' was presented in order to establish a hierarchical order of nations. The result was, as Fanon (1986:10) formulates it, that 'the black is not a man'. Having an authentic identity and being human was a privilege denied to black people.

The major problem with the recapitulation theory is that genetic ancestry is not the same as identity (Soodyall \& Reagon 2017:24). Identity is a social construct. While science has confirmed that patterns of human variation exist, it has also provided ample evidence that there is no biological or genetic basis for 'race' and that it is socially constructed (Soodyall \& Reagon 2017:16). There is no 'race' gene that is present in all members of one group but not in another. This refutes the gradation of races based on an evolutionary theory. What is more important is the identification that the 
gradation of species is a social construction without biological foundation. Gould (1981) tried to identify the abuse of science, in particular, in palaeontology and the measurement of the skull in order to determine intelligence, leading to making racist claims. According to Soodyall and Reagon (2017:27), '[t]here is no biological basis for race'. What can be said is that humans with different physical appearances are all associated with one species - all are equal human.

This confirms that identity is a social construct and as such it should be viewed as a biased activity of forming boundaries between races. It is unfortunately not only an activity of demarcating lines between groups, but has become an instrument of degradation. This process of creating and trying to prove an assigned identity has resulted in demeaning attitudes and treatment of races based on an 'alleged' black identity, which was the result of an inhumane social construction of identity.

\section{The black identity of the oppressed}

Achilles Mbembe (1957-), a Cameroon-born philosopher, has held many scholarly positions at esteemed academic institutions all over the world as well as in South Africa, and writes mainly on African history, politics and postcolonial studies. In his book Critique of Black Reason (2017), first published in French in 2013 [Critique de la raison négre], he addresses blackness as an identity.

Mbembe (2017:2-3) divides the history of blackness into three stages: enslavement, decolonisation and globalisation. Blackness becomes an identity with pejorative meaning with the coming of Atlantic slave trade (Mbembe 2017:2). Fanon (1986:231) confirms this status that people of colour were assigned: ' $[t]$ he disaster of the man of color lies in the fact that he was enslaved'. Black people from Africa were not only relocated to a different geographical environment, they were also relegated to the status of commodity, to be objectified and traded. This leads Mbembe (2017:179) to interpret the emergence of blackness to overlap with the emergence of Capitalism. Blackness has become an assigned identity by oppressors relegating black people from Africa to become the subaltern (Mbembe 2017:4), the marginalised without a voice, the item to be traded for profit. Assigning identity has become a tool of degradation, or, as Fanon (1986:16) formulates it, 'the black soul is a white man's artefact'. The emergence of slavery in the United States led to a separation of black people from North America, the Caribbean and Africa. Apparently the division created a 'double consciousness' (Mbembe 2017:25), acknowledging the existence in the Americas with a longing to return to their place of origin (Mbembe 2017:26). This return to the 'origin' also implied rediscovering the authentic meaning and identity of being black.

Under apartheid laws in South Africa, black people were also assigned an identity: as being sub-human, and subaltern. Black people were not treated equally as would be expected of fellow human beings. The assigned identity degraded black people to be considered unequal and inferior to white people, resulting in second-hand provision of housing, healthcare, education and legal representation, among other atrocities. These were manifestations of viewing black people as inferior and were based on the firm conviction that black people were not equal in any way, neither biologically nor psychologically, to the white race. With this assigned identity, black people were however not estranged from their environment as would be the case with slaves in the Americas. During apartheid, black people still resided in Africa, but now no longer owning the land they are living on. Being detached from their place of origin without being removed brought about a schizophrenic identity - in Africa but not of Africa.

With the end of slavery and for the sake of argument, the end of apartheid also, brought about the search for a new configuration of relations between black and white people. Gradual progress was made in terms of statutes regulating interaction between black and white people in society. But functionally these laws did not change the way black people were treated and surely did not change the racial bias and social processes leading to assigned identities. It emphasised the importance of the Black Consciousness Movement to create awareness of racial inequality and efforts to establish an authentic black identity. Here divergent lines followed. Some false identities were created. False identity meant that some black people wanted to be white people (Fanon 1986:228). White people still remained the measure of all things. 'The black man wants to be like the white man. For the black man there is only one destiny. And it is white' (Fanon 1986:228). Fanon (1986:93) portrays the way in which black people were taught to think of themselves. Being black implies being inferior to white people and equality can only be attained in imitating white people. This was a false identity. The true identity still remained hidden behind a (white) mask.

Biko (1987:20) identifies a different inauthentic identity forming part of the black struggle for liberation.

According to Biko, the 'black souls in white skins' are those white liberals claiming to feel the oppression as acutely as the black people and claiming that they had no participation in white racism and had struggled alongside the black people. These white liberals also have no true authentic identity as they pretend to be supportive of the black cause while they are still white people. Their white mentality causes them to advise and support black people as if white people would know what is beneficial for black people. In this instance, it is not only black people with white masks but also white people with black masks. According to Biko (1987:20), authentic black identity would consist of black people being their own guardians without white people pretending to guide and assist them in the struggle for identity.

Considerable advances in terms of establishing indiscriminate societies have been made. With the end of colonialism came 
the rise of nationalism in Africa, leading to geographical independence and regional inter-dependence. Although financial independence was not attained immediately, attempts for self-governance brought about financial progress. Intellectual independence is an ongoing process with varying success.

Ideologies of old colonisers have been replaced by new ideologies of new colonisers. The way in which nations today present their business interest in African countries obscures the ideological way in which blackness is viewed and treated. Africa still seems to be viewed as the place where resources can be plundered at the expense of and in disrespect of the local (black) inhabitants. In a postcolonial period, new attempts arise to create authentic identity.

\section{Reconstructed postcolonial black identity}

Fanon (1986:10) indicates that the question of identity is indeed the answer to the essential question as to 'what does a man want?'. ${ }^{1}$ The identity black people long for is to be recognised as being equal human (Fanon 1986:11). That is the true need.

The identity assigned to black people under colonial rule was a socially constructed identity. Being identified as black was in fact being an object invented by white people (Mbembe 2017:91). Being black is a constructed identity handed down by European thought (Mbembe 2017:2). Blackness is not only a colour but a construct created by colonists. In the relationship between races, both white and black people seem to be in need of discovering the authentic identity. The oppressor and the oppressed need to discover their true identity.

In a postcolonial paradigm there is no longer tolerance for racial superiority and racial claims to dominance. Whiteness is presented as a fantasy created by Europeans (Mbembe 2017:43-44); it is no longer a viable way of thinking or acting. Europe is however no longer the 'center of gravity of the world' (Mbembe 2017:1). This shift created opportunities for communities all over the world to discover their own identity, no longer in the light of who and what Europe said they are and ought to be, but to discover and establish a true identity. This discovering of identity can however not mean a return to the roots as if a clear and pure identity undefiled by colonialism just needs to be resuscitated and enlivened. Identity changes permanently. The growth and influences upon Africa over centuries cannot be denied, although they can be wished never to have taken place at all.

For Fanon authentic identity is not to be discovered along racial lines. Fanon wants to universalise identity to be broader than mere racial (colour) characteristics. My identity is human. Black is a nickname (a pseudonym) (Mbembe 2017:46), a cloak provided by someone else for me to wear.

1.The translator of the work by Fanon indicates that the gender-specific language ought to be ignored as the reference to 'man' implies 'women' as well.
The result is that white and black people must change (Fanon 1986:231); both must turn their backs on inhumane voices of the past. Both are held captive: black people as being inferior and white people held captive by superiority (Fanon 1986:231). Under a new paradigm a new identity is to be created for both white and black people.

Whether a new authentic black identity has already been established is doubtful. Have the fears of a subtle white dominance that Fanon has expressed been allayed? Has the plea of Fanon to be acknowledged not according to race but as fellow human being been heard? Doubtful! Will this authentic identity ever be established? Marriott (2018:ix), as by own account, is pessimistic about the future of black identity.

As to whether the white matrix will change so that black can be black, Marriott (2018:ix) honestly proclaims that he does not know. This uncertainty is not a case of being unsure if it will happen but rather being doubtful that it will ever happen. For Marriott, the statement made by Fanon (1986:10) that 'for the black man there is only one destiny and that is white' seems to hold some truth to it. There is still a waiting for blackness to arrive in the New World (Marriott 2018:xviii). It seems as if the construction of the black identity where there are shackles of slavery and the bondage of an assigned identity has not yet been shed, and therefore the formation of an identity is still underway.

To identify oneself one needs to recognise oneself (Mbembe 2017:151). One needs to discover one's own identity, shed the assigned identity. As Appiah (2002) indicated, with an identity change comes the change in behaviour. A new identity requires a new way of acting and behaving, and no longer living up to the stereotyped and expected behaviour by those who assigned the identity, now living independently according to the own authentic identity. As true authentic identity, Fanon indicated that black people should consider their identity not to be the signifier Black, but accept the identity of being human (Fanon 1986:93). To be human is to recognise the human in other.

Masango (2006) emphasises the discovering of our humanity through the principle of Ubuntu: I can become human once I recognise you to be human. Humans learn one to be human (Fanon 1986:217). Can Ubuntu prove to be the solution to the search for an authentic identity of white and black people?

What is the identity of being black?

The problem is most certainly not being assigned the identity of being black. The sentiment and stereotype associated with black come along as part of the identity. To be called black was never and still is not intended to be flattering nor is it a compliment (Mbembe 2017:152).

To discover one's own identity involves an identification of differences - being me and not the other. 
The problem that Mbembe (2017:90, 94) identifies is that identities assigned may be done based on a valuation system, where some identities are presented as if they are of higher value and quality than others. Black assigned identities were in the past viewed as if being inferior to white identities. Therein lies the problem - not differences but inequalities. According to Mbembe (2017:151), a part of discovering and formulating identity consists of not only recognising oneself but also an affirmation of existence - the need for recognition that Fanon (1986:10) talked about. To indicate how one identifies oneself is already an act of acknowledging that one indeed exists.

Mbembe (201789) is of opinion that the process of establishing a black identity is still trapped in a tension from which it has not yet escaped. The trap is created by the question whether black people are indeed part of a generic humanity, for so long black people have been denied the identity of belonging to the human race.

As Maluleke (2000:28) explains, there is 'a new wave of awareness of the agency of ordinary marginalised Africans'. He explains that the agency of African Christians and the African poor is being rediscovered, explored and respectfully interpreted (Maluleke 2000:31). The finding and search for a new identity start with the awareness of the absence thereof. The exploration for identity must be undertaken with respect to diversity even within the black community. There is not only one black identity. Identity is cultural expressions, and culture cannot be defined along colour codes. The differences and nuances need to be acknowledged. The differences between tribal communities are evident from the tribal struggles that occurred over many decades - for example, between Huts'i's and Tutsi's, among the inhabitants of Sudan and South Sudan. In the movie Black Panther, the fictional tribal diversity is also portrayed, reflecting reality.

There are many identities to be considered. The diversity becomes more complex when one considers the different religions impacting identity in Africa. The way in which Islam and Christianity have contributed to the demarcation between communities in Africa needs to be acknowledged. The impact of the presence of Asians in Africa has not been as evident as yet, but may prove to be considerable in the amount of migrant workers from the East residing in Africa.

The crucial point of this article is to emphasise the need for authentic identity. This is the need of white people as well as black people. Identity seems not to lie in race. Race only divides and obscures. True identity lies in discovering a shared humanity. All belong to the human race, making all equal. Once the humanity of all has been recognised, one needs to tread others based on shared moral humane principles. Masango suggests that this shared humanity is to be discovered in the principle of Ubuntu: only in the eyes of other humans I become human too. Once equal status of humans has been discovered and acknowledged, people can treat one another decently.

The concept of Ubuntu, however, is in need of critical reflection. Ubuntu can easily be seen as the reduction of humanity to the familiar. Equality and recognition of the humanness of the other are not only to be extended to family, clan or tribal members. Then Ubuntu retains an exclusivity as to who is recognised and who is not. Ubuntu needs to be defined in terms of acknowledging the human in others, irrespective of the race, language and descendancy of the other.

White identity is also in need of change. Black identity is either assigned and in need of reconstruction or false identity with a mask. Fanon (1986:231) confirms this expectation from white and black people: ' $[b]$ oth must turn their backs on the inhuman voices which were those of their respective ancestors in order that authentic communication be possible'. White identity as the oppressor and racist assigning others identity also needs to change. Both white and black people need to reach an authentic identity (cf. Appiah 2002) as to who we really are. Only then with authentic identities can white and black together in synergised effort address common injustices and challenges faced in society.

Appiah (2002:388) suggests that the identities we need will have to focus on two elements: to recognise the differences among human identities and to recognise the moral unity of humanity. Reaching authentic identities for white and black people does not imply convergence or overlapping of identities. Identities need to acknowledge the differences that exist between identities. Once both white and black people have acknowledged the differences, both having attained authentic identities can now together face challenges in society. With diversity we can still unite as humanity and treat fellow humans with dignity and respect while simultaneously direct our efforts at addressing social and ecological injustices.

According to Fanon, the identity of being black is in fact being human. '... I recognize that I have one right alone: That of demanding human behaviour from the other' (Fanon 1986:229). This theme is identified by Mbembe (2017:89) as the central theme in Fanon's work.

Masango is an example of a scholar willing to participate in conversations with other identities seeking together in collaborated effort the end of social injustices while each maintaining its own identity and working together in unity towards a common goal. In this way, Masango (2006:932) applies the suggestion of Appiah that the two principles need to be applied: recognising differences and recognising unity of humanity. Masango has however a unique way of perceiving the differences and unity of humanity. 
According to Masango (2006:932), black identity and African spirituality centre around the concept of Ubuntu. For Masango (2006:938), Ubuntu entails mutual respect among human beings, respect for elders and commoners alike. In the communality of existing together, one discovers the true meaning and wholeness of life (Masango 2006:939), giving expression to the understanding of Ubuntu as the way of life whereby a person is considered a person because of other people. Appiah (2002:388) confirms this: '... the identities we need will have to recognize both the centrality of difference within human identity and the fundamental moral unity of humanity'.

Fanon (1986:216) formulates it as follows: ' $[m]$ an is human only to the extent to which he tries to impose his existence on another man in order to be recognized by him'. This mutual recognition grants human beings the privilege to be considered human not only by the self but also by others. This process of recognition is reciprocal according to Fanon (1986:217).

This characteristic of Africans to be able to recognise the unity of humanity was lost during the apartheid era in South Africa, causing life to lose its meaning. Restoring Ubuntu will once again assist in finding a new identity which will transcend the ethnic divisions of Africa (Masango 2006:942). Restoring Ubuntu means to discover and restore in humanity the image and likeness of God. This will cause humanity to respect each other. Ubuntu will instil values that will shape the next generation who will work towards peace (Masango 2006:942). Ubuntu implies the restoring of the image of God in humanity. Identity is to be found in God. For this insight, we must thank prof Masango in that we can find hope in the possibility of peacefully co-existing as human beings, racially diverse, but in unity searching for peace.

In the end of the movie Black Panther, the hero manages to lead his people in an altruistic process of sharing their unique technology with the rest of the world in order to create communities where hope and meaning are restored. In the light of Masango's suggestion of Ubuntu as the restoring of identity, the movie Black Panther illustrates the effect of sharing and caring with and for others.

\section{Acknowledgements Competing interests}

The author has declared that no competing interests exist.

\section{Author(s) contributions}

I declare that I am the sole author of this research article.

\section{Ethical consideration}

This article followed all ethical standards for a research without direct contact with human or animal subjects.

\section{Funding information}

This research received no specific grant from any funding agency in the public, commercial or not-for-profit sectors.

\section{Data availability statement}

Data sharing is not applicable to this article as no new data were created or analysed in this study.

\section{Disclaimer}

The views and opinions expressed in this article are those of the author and do not necessarily reflect the official policy or position of any affiliated agency of the author.

\section{References}

Appiah, K.A., 2002, 'Race, culture, identity: Misunderstood connections', in P.H. Coetzee \& A.P.J. Roux (eds.), Philosophy from Africa: A text with readings, pp. 373-390, 2nd edn., Oxford University Press Southern Africa, Cape Town.

Beyers, J., 2017, 'Religion and culture: Revisiting a close relative', HTS Teologiese Studies/Theological Studies 73(1), a3864. https://doi.org/10.4102/hts.v73i1.3864 Biko, S., 1987 [1978], I write what I like, Heinemann Publishers, Oxford.

Boyer, P., 2001, Religion explained, Basic Books, New York.

Fanon, F., 1986, Black skin, white masks, transl. C. Markmann, Pluto Press, London.

Gould, S.J., n.d., Racism and recapitulation, viewed 02 March 2019, from www. sjgouldessays.com/content/nh_essay_summaries_content/01\%20Ever\%20 Since\%20Darwin.pdf.

Gould, S.J., 1981, The Mismeasure of Man, W.W. Norton \& Company, New York.

Lincoln, B., 1989, Discourse and the construction of society, Oxford University Press, Oxford.

Maluleke, T.S., 2000, 'The rediscovery of the agency of Africans: An emerging paradigm of post-cold war and post-apartheid black and African theology', Journa of Theology for Southern Africa 108, 19-37.

Manganyi, N.C., 1973, Being-Black-in-the-world, SPRO-CAS, Johannesburg.

Marriott, D., 2018, Whither Fanon? Studies in the Blackness of Being, Stanford University Press, Stanford, CA.

Masango, M.J.S., 2006, 'African spirituality that shapes the concept of Ubuntu', Verbum et Ecclesia 27(3), 930-943. https://doi.org/10.4102/ve.v27i3.195

Mbembe, A., 2017, Critique of black reason, transl. L. Dubois, Wits University Press, Johannesburg.

Soodyall, H. \& Reagon, F., 2017, 'Human variation: What can we learn from Genetics', in C. Ballantine, M. Chapman, K. Erwin \& G. Maré (eds.), Living together, living apart: Social cohesion in a future South Africa, pp. 16-28, UKZA Press, Durban.

UNESCO, 2002, UNESCO Universal Declaration on Cultural Diversity, adopted by the 31st Session of the General Conference of UNESCO, Paris, 02 November 2001, viewed 08 February 2019, from http://www.un-documents.net/udcd.htm.

Vroom, H., 1996, Religie als ziel van cultuur: Religieus pluralisme als uitdaging, Meinema, Zoetemeer.

Woodhead, L., 2011, 'Five concepts of religion', International Review of Sociology 21(1), 121-143. https://doi.org/10.1080/03906701.2011.544192

Zacharek, S., 2018, 'Black Panther is a movie for everyone', Time Magazine, 26 February, p. 88 